\title{
Cultural Values In The Sariga Tradition From Muna Tribe In Indonesia
}

\author{
Saidiman $^{1}$, Sumiyadi ${ }^{2}$, Iskandarwassid ${ }^{3}, \&$ Tedi Permadi ${ }^{4}$ \\ \{saidiman@uho.ac.id ${ }^{1}$, sumiyadi@upi.edu², iskandarwassid@upi.edu ${ }^{3}, \&$ tedipermadi@upi.edu ${ }^{4}$ \} \\ ${ }^{1234}$ Postgraduate School, Indonesian Language Study Program, \\ Indonesian Education University
}

\begin{abstract}
This research examines the cultural values in the Sariga tradition from Muna in Indonesia. Muna is one of the tribes in Southeast Sulawesi, Indonesia. Muna is rich in regional culture and upholds customs in the process of life in society. Education in the Muna community is not only focused at school. However, from childhood to adulthood has been educated in a family environment with a cultural approach. The cultural approach in this case, the young generation in Muna society was introduced to know the types of culture that exist in their area, one of the aim is that the values contained in the local tradition can be embedded in them. One of tradition that has cultural values is the Sariga tradition. The problem in this research is "what cultural values are contained in the Sariga tradition from Muna in Indonesia?" The aim of this research is to describe the cultural values contained in the Sariga tradition from Muna in Indonesia. The methods used are the ethnographic method, cultural research method, and field method. The theories used in this research are theory, culture, local wisdom, oral tradition, and cultural values. The results showed that, there are several cultural values contained in the Sariga tradition, namely religious values, family values, beauty values, mutual cooperation values, education values, and economic values.
\end{abstract}

Keywords: Culture, Oral Traditions, Local Wisdom, The Sariga Tradition, Culture Values, Muna Tribe.

\section{Introduction}

The Indonesian people have character values that are reflected in the tradition and customs adopted by the society until now. Life values taught in local locality become the moral base in every action and behavior of the society. The values of local wisdom which make diversity of the nation can coexist in peacefulness and unity. The values of local wisdom in a society become something held in high esteem by certain people. Various methods are used so that local values continue to live and survive in society. Over time and increasing globalization, it does not rule out the possibility of local values to change by the times. In the Muna community, local values are applied in each particular tradition which is conveyed through traditional actors who are competent in their respective fields. 
The process of education based on local cultural in Muna community has been going on for a long time and has been applied for generations and the process of inheritance has continued from one generation to the next generation. Until now the process of education based on cultural traditions is still maintained but as a result of the development of technology slowly began to fade. Education through local traditions in the Muna community is carried out by the traditional actors who are trusted by the community as having knowledge of the values of character in the local wisdom.

One of oral tradition that has many values is the Sariga tradition. The Sariga tradition is a teaching given for humans to be grateful of Allah SWT creation. The teachings of the Sariga tradition teach that humans were created in the world not by chance, but that some created them to be born in this world. However, by the times, this tradition began to erode and almost no implementation in the Muna community. That is why this research is very important to carry out.

\section{Research Methods}

The approach used in this research is a qualitative approach. The reason for using this approach is because it wants to describe data or research targets as a whole without reducing or isolating the phenomenon of the Sariga tradition in Muna society.

Creswell [1] explains that a qualitative approach focuses on information about the main phenomenon (central phenomenon) in general that explored in research, study participants, and research locations.

The method used in this research is ethnographic research method and cultural research method. Ethnographic method is used to uncover and describe the socio-cultural context of the Sariga tradition from Muna tribe [2]. While cultural research methods are used to look at the phenomena that occur as a whole of the Sariga tradition [3].

\section{Results And Discussion}

Based on the findings in the field, there are several values contained in the Sariga tradition from Muna tribe, namely religious values, educational values, family values, beauty values, mutual cooperation values, and economic values.

Endraswara [4] explains that culture is something that lives, develops, and moves towards a certain point.

Koentjaraningrat [5] mentions that there are seven elements of culture that can be found in all nations of the world. The seven elements that we can say the principal of each culture in the world are: (1) language, (2) knowledge systems, (3) social organization, (4) living equipment and technology systems, (5) living livelihood systems, (6) religious system, (7) artistry.

Hutomo [6] The term of oral tradition is a translation of the oral tradition. With this concept, the same as its understanding with folklore, the difference only lies in the action that is transmitted orally, which is sometimes followed by action.

Hereinafter he explained that there were three types of verbal statements, namely: (1) the birth of a witness; (2) oral traditions (specifically); and (3) hearsay. 
Lord [7] oral traditions are things spoken in society. The purpose of that explanation is in conveying the oral tradition, the oral element for the speaker and the listening element for the recipient are the keywords of the oral tradition. The speaker does not write what is spoken and the recipient does not read what he receives. However, the concept of Lord emphasizes more on the oral process that occurs in the form of traditional activities.

Sibarani [8] oral tradition is the traditional cultural activity of a society which is passed down through generations with oral media from one generation to another, both traditions in the form of words (verbs) or non-verbal (non-verbal).

Vansina [9] in general, oral tradition as all kinds of verbal information in the form of reports about something that happened in the past, becomes a histology from the past, and information about how it is interpreted. Information in the oral tradition concerns verbal messages in the past that are spoken, sung or delivered through music and sounds.

Deidre A. Kramer [10] which shows the function of wisdom is as follows: (1) solutions to problems faced by yourself, (2) giving advice to others, (3) managing institutions social, (4) examine life, (5) spiritual introspection.

Kuntoro [11] local wisdom is used to indicate the existence of a concept that in local sociocultural life there is a nobleness, height of values, truth, goodness and beauty that are valued by citizens so that it is used as a guide or guideline for building relationships pattern between citizens or as a basis for building the goals of their lives to be realized. Local wisdom is a characteristic or excellence possessed by each region that can be utilized to build Indonesian human civilization.

Sibarani [12] local wisdom is the original source or information of the society that is related to the noble values of cultural traditions to get the order of people's lives.

Sedyawati [12] oral traditions become habitual deposits that become norms or rules that are agreed upon and carried out by the society in daily life.

The Sariga tradition is a form of ritual that is implemented in the Muna community when a domestic life has been blessed with a pair of children between a boy and a girl. If in one family already has children between men and women, the person concerned will carry out the Sariga ritual by summoning the customary head who understands in the implementation of the Sariga tradition.

Marta de la Torre [13] Values are most often used in one of two senses: first, as morals, principles, or other ideas that serve as guides to action (individual and collective); and second, in reference to the qualities and characteristics seen in things, in particle snake the positive characteristics (actual and potential).

Furthermore Marta de la Torre [14] explains that sociocultural values are at the traditional core of conservation - values inherent in an object, building, or place because it has meaning for people or groups social because of age, beauty, art, or relationships with people or events that are significant or (vice versa) contribute to the process of cultural relations. There are several parts of socio-cultural values, namely: (1) historical value, (2) symbolic value, (3) social value, (4) spiritual/ religious value, (5) aesthetic value.

A sociologist Talcott Parson, argue that values is "the most important element of social life". Psychologically, Rokeach sees values as "personal disposition as well as attitude, but deeper than attitude even becomes the basis for attitude". As for Hofstede's view of values as "a broad tendency to choose one thing over another" [14].

Another formulation of values described by Halstead and Taylor [15] values according to both have many formulas that are usually associated with something that is considered "good" in him, such as beauty, truth, love, honesty and loyalty, and value as a social or personal choice. Both then explain, the term value is usually used to show the principles, basic beliefs, 
ideals, living standards that guide behavior, or reference points in making decisions or evaluations of beliefs or actions, related to integrity and personal identity.

Values help individuals understand, decide, and even exist. Values endow individuals with a normative language that allows them to distinguish and judge their own behavior. And this allows them to decide on courses of action, and to preserve self-esteem and values help society to convey information, facilitate coordination, and give the group an identity. Precisely because they share values, the members of a society can interpret the behavior of other members and establish expectations about it. Through the sharing and communication of values, the behavior of individuals can be coordinated and made cohesive. Building a community essentially involves aligning people with shared values [16].

Bertens [17] there are three characteristics of values in oral tradition, namely: (1) values related to the subject, which means that if there are no subjects to judge, there is no value either, (2) values appear in a practical context in which the subject wants to make something, and (3) the value concerns the attributes added by the subject to the properties possessed by the subject.

Koentjaraningrat [18] cultural values is a value system that refers to the good and bad behavior of the society based on its practice of the value system used as a way of life. The way of life concerns human nature in relation to oneself, other human beings, nature, and His creator [19]. There are several values of life in society that are used as guidelines in social life, namely: (1) family values, (2) religious values, (3) social values, (4) beauty values, (5) economic values, (6) political values, (7) mutual cooperation value.

Culture Values in Sariga Tradition From Muna Tribe.

a. Religious Value

The religious value contained in the Sariga tradition in terms of human relations with the creator of God Almighty, God the creator of heaven and earth and its contents. The religious value contains the way how humans get closer to Allah SWT through prayer and gratitude. Prayers performed by the Sariga ritual performers together with the people involved in the Sariga tradition beg God to always given health, to be give with sustenance, blessed with all the activities for life in the world, and always protected from spirits evil and all acts of evil that will be close to him.

b. Educational Value

The educational value contained in the Sariga tradition from Muna tribe is reviewed from the oaths given by ritual performers to children in Sariga, so that they always respect their parents, siblings, neighbors, and society in general. The ritual performers advised them to become pious children and be dedicated to their parents.

c. Family Value

The family value contained in the Sariga tradition is viewed in terms of the relationship between society members. In the implementation of the Sariga tradition, the society starts from the sub-district head, the village head, community leaders, traditional leaders, and they hold deliberations to determine decisions together and then involve society members by helping together to realize the activities of the Sariga tradition

d. Beauty Value

The value of beauty in the Sariga tradition is reviewed of aesthetics, beauty in the Sariga tradition is manifested in the form of traditional clothes used by ritual practitioners and the society involved in the implementation of the Sariga tradition. Besides that, another beauty was also shown by the presence of local silat which was carried out by several people in closing the traditional activities. 


\section{e. Mutual Cooperation Value}

The value of mutual cooperation in the Sariga tradition from Muna tribe is viewed from togetherness in completing the process of implementing the tradition from beginning to the end. The society supports the continuity of the tradition in an orderly and peaceful manner until it is finished. This reflects the concern of the society care between fellow people.

f. Economis Values

The economic value in the Sariga tradition from Muna tribe is viewed from the society who come to watched the Sariga ritual, they give a sum of money wrapped in white paper. People who watched the ritual voluntarily give monetary contributions without being asked.

\section{Conclusion}

Based on the result of the research, it can be concluded that the Sariga tradition from Muna tribe in Muna District, Southeast Sulawesi Province, needs to be preserved because it is almost no longer practiced and most of the Muna people are not familiar with the tradition. Furthermore, the importance of the Sariga tradition is preserved because it has very interesting cultural values to be maintained so that it can be created a harmonious life in the society.

There are several cultural values contained in the Sariga tradition, namely religious values, educational values, family values, beauty values, mutual cooperation values, and economic values. Encounter the development of today's which goes by so fast and technological sophistication, where individuals are more busy by prioritizing their personal interests so that the lifestyle of mutual assistance, mutual help, are very rare in the society environment in general. Therefore, the Sariga tradition is very necessary and important for its existence to remain alive in the Muna community, even the cultural values in the Sariga tradition can be spread in various regions other than the Muna community whose multi-cultural lifestyle in order to maintain harmonious relations among members of the community.

\section{References}

[1] J. Creswell, Research Design "Pendekatan Metode Kualitatif, Kuantitatif, dan Campuran. Yogyakarta: Pustaka Pelajar, 2017.

[2] J. P. Spradley, Metode Etnografi. Yogyakarta: Tiara Wacana, 2007.

[3] Maryaeni, Metode Penelitian Kebudayaan. Jakarta: Bumi Aksara, 2008.

[4] S. Endraswara, Metodologi Penelitian Kebudayaan. Yogyakarta: UGM Press, 2012.

[5] Koentjaranigrat, Pengantar Ilmu Antropologi. Jakarta: Rineka Cipta, 2009.

[6] S. S. Hutomo, Mutiara yang terlupakan. Surabaya: Himpunan Sarjana Keusastraan Indonesia, 1991.

[7] A. B. Lord, The Singer of Tales. London: Harvard University Press, 2000.

[8] R. Sibarani, Kearifan Lokal (Hakikat, Peran, dan Metode Tradisi Lisan. Jakarta: ATL, 2012.

[9] J. Vansina, Tradisi Lisan sebagai Sejarah (Terjemahan dari Oral Tradition as History). Yogyakarta: Ombak, 2014.

[10] R. H. Trowbridge, "Project Demonstration Ecellence the Scientific Approach of Wisdom," Disertasi, 2005.

[11] A. Kuntoro, Sodiq, "Konsep Pendidikan Berbasis Kearifan Lokal sebagai Dasar Pembentukan Karakter Bangsa," Pros. Semin. Nas. Ilmu Pendidik., 2012.

[12] E. Sedyawati, Kedudukan Tradisi Lisan dalam Ilmu-Ilmu Sosial dan Ilmu-Ilmu Budaya. Jakarta: Warta Asosial Tradisi Lisan, 1996. 
[13] Ma. de la Torre, "Assessing the Values of Cultural Hertage," Los Angles: The Getty Conservation Institute, 2000.

[14] A. Sanusi, Pendidikan untuk Kearifan "Mempertimbangkan Kembali Sistem Nilai, Belajar, dan Kecerdasan. Bandung: Anggota IKAPI, 2017.

[15] M. J. Halstead, J.M. and Taylor, Values in Education and Edication in Values. Bristol: The Falmer Press, 1996.

[16] H. K. et all Keller, Global NEtwork and Local Values A Comparative Look at Germany and the United States. Washington D.C: National Academy Press, 2001.

[17] O. K. S. Zaimar, Metodologi Penelitian Sastra Lisan dalam Metodologi Kajian Tradisi Lisan. Jakarta: ATL, 2015.

[18] Koentjaranigrat, Pengantar Ilmu antropologi. Jakarta: Rineka Cipta, 2005.

[19] K. Saddhono, "Integrating Culture in Indonesian Language Learning for Foreign Speakers at Indonesian Universities." J. of Lang. and Lit. vol. 6 no.2 pp. 349-353, 2015 